\title{
Pengembangan SIVAJAR : Sistem Informasi Evaluasi Belajar Berbasis Web (Studi Kasus : SMK Negeri 3 Singaraja)
}

\author{
I Gede Dedy Prasetia1), I Gede Mahendra Darmawiguna2), Gede Aditra \\ Pradnyana ${ }^{3)}$ \\ ${ }^{1}$ Fakultas Teknik dan Kejuruan, Universitas Pendidikan Ganesha(penulis 1) \\ email: dedyprasetia@gmail.com \\ ${ }^{2}$ Fakultas Teknik dan Kejuruan, Universitas Pendidikan Ganesha(penulis 2) \\ email: mahendra.darmawiguna@undiksha.ac.id \\ ${ }^{3}$ Fakultas Teknik dan Kejuruan, Universitas Pendidikan Ganesha(penulis 3) \\ email: gede.aditra@undiksha.ac.id
}

\begin{abstract}
Abstrak
Penelitian ini bertujuan : (1) Menghasilkan rancangan dan mengembangkan SIVAJAR : Sistem Informasi Evaluasi Belajar Berbasis Web (Studi Kasus : SMK Negeri 3 Singaraja), (2) Mengetahui respon guru dan siswa terhadap implementasi SIVAJAR : Sistem Informasi Evaluasi Belajar Berbasis Web (Studi Kasus : SMK Negeri 3 Singaraja).

Penelitian ini merupakan jenis penelitian dan pengembangan dengan model waterfall, yaitu model yang bersifat sistematis dan berurutan dalam membangun perangkat lunak, mulai dati tahap analisis, desain, implementasi, dan pengujian. Analisis dilakukan melalui observasi dan wawancara langsung dengan wakasek kurikulum, guru dan siswa SMK Negeri 3 Singaraja.

Implementasi penelitian ini menggunakan bahasa pemrograman PHP dan Javascript dengan framework laravel serta Sublime sebagai code editor. Pengujian SIVAJAR (Sistem Informasi Evaluasi Belajar) Berbasis Web (Studi Kasus : SMK Negeri 3 Singaraja) dilaksanakan dalam 3 tahap yaitu : (1) Pengujian blackbox (pengujian fungsionalitas) diperoleh seluruh proses telah mampu berjalan dengan baik, (2) Pengujian whitebox (pengujian prosedural) diperoleh pengimplementasian algoritma telah berhasil, (3) Pengujian usibility testing diperoleh sistem sudah efektif dan efisien serta untuk kepuasan pengguna telah menghasilkan bahwa pengguna merasa puas menggunakan SIVAJAR : Sistem Informasi Evaluasi Belajar Berbasis Web (Studi Kasus : SMK Negeri 3 Singaraja).
\end{abstract}

Kata kunci: Evaluasi Belajar, Sistem Informasi, Web, SMK

\begin{abstract}
The study aimed to : (1) Produce design and develop SIVAJAR : Information System Evaluation Study Web Based (case study : SMK Negeri 3 Singaraja) (2) Knowing the response of teachers and students on the implementation SIVAJAR : Information Systems Evaluation Study Web Based (case study : SMK Negeri 3 Singaraja)

This study was conducted types of research and development with the waterfall model is a model which is systematic and sequential in building software, starting from the analysis, design, implementation, and testing. The analyzed were conducted through direct observation and interviews with the vice principal areas of curriculum, teachers and students SMK Negeri 3 Singaraja.

Implementation of this study using the programming language PHP and Javascript with laravel framework and Sublime as a code editor. Testing SIVAJAR (Information System Evaluation Study) Web-based (Case Study: SMK Negeri 3 Singaraja) carried out in three stages: (1) Blackbox testing (testing functionality) acquired the entire process has been able to walk properly (2) White-box testing (testing procedural) obtained by the implementation of the algorithm has been successful,(3) Testing obtained usibility testing system is effectively and efficiently and to the satisfaction of users has resulted that the user is satisfied using SIVAJAR :
\end{abstract}




\begin{abstract}
Information System Evaluation Study Web-based (Case Study: SMK Negeri 3 Singaraja)
\end{abstract}

Keywords : Evaluation Studi, Information System, Web, SMK

\section{PENDAHULUAN}

Evaluasi hasil belajar dalam dunia pendidikan dilakukan terhadap anak didik untuk mengetahui tingkat kemampuan atau keberhasilan selama menjalani proses pendidikan. Untuk tingkat sekolah proses evaluasi hasil belajar dilakukan melalui pengamatan langsung oleh guru yang terlihat dalam proses pendidikan terhadap siswa dan dilakukan penilaian melalui satu tes atau disebut juga ujian. Ujian diselenggarakan untuk mengevaluasi sejauh mana mahasiswa memahami sebuah materi yang sudah diberikan. Hasil evaluasi ini yang nantinya dijadikan sebagai ukuran tingkat pencapaian tujuan belajar mengajar dan tingkat keberhasilan siswa mencapai tujuan yang ditetapkan dalam sebuah program. Ujian atau tes ini dilakukan secara berkala atau rentang waktu tertentu selama masa pendidikan. Pada lembaga pendidikan kegiatan ujian dilakukan dengan dua cara, baik secara tertulis maupun secara praktek. Termasuk juga Sekolah Menengah Kejuruan, dalam satu semester minimal dilakukan dua kali tes atau ujian, yaitu ujian tengah semester dan ujian akhir semester.

Pelaksanaan ujian yang dilakukan di sekolah-sekolah, termasuk pada sekolah menengah kejuruan(SMK), masih banyak dilakukan secara konvensional yang memerlukan waktu, biaya, dan tenaga yang cukup banyak. Kegiatan ujian semester biasanya diawali dari pembuatan soal dari guru bidang studi, soal yang dibuat oleh guru akan digandakan pihak akademis. Kemudian untuk mengetahui hasilnya, jawaban siswa akan dikumpulkan lalu dikoreksi oleh guru bidang studi dan siswa tidak bisa langsung mengetahui hasil atau nilainya.

Berdasarkan observasi dan hasil wawancara yang dilakukan di SMK Negeri 3 Singaraja didapatkan bahwa pelaksanaan ujian masih dilakukan secara manual dan menggunakan aplikasi wondershare QuizCreator yang bersifat statis, sehingga menyebabkan pelaksanaan ujian kurang berjalan dnegan baik, serta belum mampu memberikan variasi soal yang lebih banyak dan data soal masih terpisah-pisah yang dibawa oleh masing-masing guru pengampu mata pelajaran. Permasalahan yang ditimbulkan akibat belum adanya sistem ujian yang lebih kompleks dan data terpusat adalah (1) Pengumpulan soal dari guru pengampu masing-masing mata pelajaran ke panitia ujian menjadi lambat (2) Soal yang ditampilkan kurang bervariasi karena jenis soal cuma pilihan ganda (3) Hasil jawaban yang tidak tersimpan ke basis data karena masih menggunakan sistem yang statis, membuat data jawaban siswa akan hilang ketika terjadi masalah pada komputer atau mati listrik (4) Remidial masih menggunakan soal yang sama dengan soal ujian dan belum ada pembahasan soal (5) Laporan hasil ujian masih dicatat secara manual oleh pengawas ujian sehingga memerlukan waktu yang lama dan bisa saja terjadi kesalahan dalam mencatat hasil ujian. Selain permasalahan di atas juga terdapat permasalahan lain yaitu kebutuhan informasi nilai ujian siswa di sekolah merupakan sarana penunjang kegiatan akademik yang sangat penting untuk diketahui oleh orangtua siswa. Penyampaian informasi nilai akademik siswa di sekolah pada umumnya dilakukan setiap penerimaan raport saja. Orang tua siswa tidak mengetahui perkembangan berapa nilai yang diperoleh siswa dalam satu mata pelajaran karena siswa kurang terbuka dengan masalah nilai yang diperoleh di sekolah.

Sistem evaluasi yang mampu melakukan penyimpanan data terpusat ke basis data serta dapat memberikan soal yang lebih banyak dan bervariasi dengan didukung oleh teknologi SMS gateway untuk mempermudah penyebaran informasi nilai secara langsung pada orang tua siswa sangat perlu dikembangkan di SMK Negeri 3 Singaraja sehingga pengolahan data evaluasi hasil belajar siswa dan proses 
evaluasi bisa berjalan dengan cepat dan efisien.

Penelitian terkait yang dilakukan oleh Nurhadianto(2015) yang berjudul Sistem Informasi Ujian Berbasis Web Server SMK Bina Islam Mandiri (Bisma) Kersana Brebes Tegal. Penelitian terkait lain dilakukan oleh Pratiwi(2015) yang berjudul Pengembangan Sistem Informasi Nilai Ujian Online Dengan Gammu.

Berdasarkan permasalahan di atas, maka dalam penelitian ini penulis mengambil judul "Pengembangan SIVAJAR (Sistem Informasi Evaluasi Belajar) Berbasis Web (Studi Kasus : SMK Negeri 3 Singaraja)". Diharapkan sistem ini mampu melakukan proses evaluasi dengan lebih mudah dan efisien, bermanfaat bagi guru dan siswa dengan memanfaatkan kemajuan teknologi yang lebih canggih.

\section{Evaluasi Pembelajaran}

Evaluasi pembelajaran adalah evaluasi terhadap proses belajar mengajar. Secara sistemik, evaluasi pembelajaran diarahkan pada komponenkomponen sistem pembelajaran, yang mencakup komponen input, yakni perilaku awal (entry behavior) siswa, komponen input instrumental, yakni kemampuan profesional guru/tenaga kependidikan, komponen kurikulum (program studi, metode, media), komponen administratif (alat, waktu, dana); komponen proses ialah prosedur pelaksanaan(Jihad,2008).

\section{Pelaksanaan evaluasi pembelajaran pada SMK}

Sekolah Menengah Kejuruan (SMK) sebagai salah satu lembaga pendidikan di bidang kejuruan mempunyai tujuan menyiapkan calon tenaga kerja yang memiliki pengetahuan, keterampilan dan kemampuan berwirausaha untuk mengisi lapangan pekerjaan baik ditingkat lokal, nasional, maupun internasional. Sesuai dengan namanya sebagai sekolah kejuruan, maka sistem pembelajaran yang diterapan yaitu teori dan praktikum(Syah, 2004).

\section{Aspek Evaluasi Pembelajaran}

Evaluasi atau penilaian pada SMK dilakukan pada 3 aspek yaitu Penilaian kognitif(pengetahuan),

Penilaian

psikomotorik(ketrampilan) dan Penilaian afektif(sikap). Pada sistem yang dikembangkan akan melakukan proses evaluasi pada ranah kognitif (pengetahuan) dimana penilaian dilakukan melalui penugasan, penilaian harian $(\mathrm{PH})$, ujian tengah semester (UTS), maupun ujian akhir semester (UAS) (Gunawan, 2015).

\section{Instrumen Evaluasi Pembelajaran}

Instrumen merupakan suatu alat yang memenuhi persyaratan akademis, sehingga dapat dipergunakan sebagai alat untuk mengukur suatu obyek ukur atau mengumpulkan data mengenai suatu variabel. Dalam bidang pendidikan instrument digunakan untuk mengukur prestasi belajar siswa, factor-faktor yang diduga mempunyai hubungan atau berpengaruh terhadap hasil belajar, perkembangan hasil belajar siswa, keberhasilan proses belajar mengajar guru, dan keberhasilan pencapaian suatu program tertentu. Adapun instrumen yang digunkan adalah tes tertulis yaitu tes subjektif dan objektif yaitu 1) tes essay, 2) tes pilihan ganda, (2) tes salah benar, (4) tes jawaban pendek dan (5) tes calculated.

\section{Freamwork Laravel}

Secara sederhana framework dapat diartikan sebagai kumpulan dari fungsi atau prosedur dan class untuk tujuan tertentu yang sudah siap untuk digunakan sehingga mempermudah dan mempercepat programmer dalam membuat program tanpa harus membuat fungsi atau class dari awal. Pada framework sudah tersedia struktur aplikasi yang baik seperti standard coding, best practice, design pattern dan common function sehingga programmer dapat langsung fokus kepada proses pembangunan sistem tanpa harus melakukan mindset atau berpikir pada masalah struktur aplikasi, standard coding dan lain sebagainya(Ardana, 2013).

\section{GAMMU}

GAMMU (GNU All Mobile Management Utilities) merupakan software yang digunakan sebagai tool untuk mengembangkan aplikasi SMS Gateway, 
cukup mudah diimplementasikan, dan tidak berbayar. Gammu adalah semacam service yang disediakan untuk membangun aplikasi yang berbasis sms gateway dan ditujukan untuk membangun aplikasi, script dan drivers yang dapat digunakan untuk semua fungsi yang memungkinkan pada telepon seluler atau alat sejenisnya. Sekarang gammu telah menyediakan codebase yang stabil dan mapan untuk berbagai macam model telepon yang tersedia di pasaran dibandingkan dengan project sejenis. Gammu merupakan project yang berlisensi GNU GPL 2 sehingga menjamin kebebasan menggunakan tool ini tanpa perlu takut dengan masalah legalitas dan biaya yang mahal yang harus dikeluarkan. Gammu mendukung berbagai macam model telepon seluler dengan berbagai jenis koneksi dan type(Acho, 2008).

\section{Penelitian Terkait}

Beberapa penelitian terdahulu yang membahas tentang pengembangan sistem evaluasi belajar atau ujian online, antara lain sebagai berikut: Nurhadianto(2015) Mengembangkan Sistem Informasi Ujian Berbasis Web Server SMK Bina Islam Mandiri (Bisma) Kersana Brebes Tegal. Pratiwi(2015) Mengembangkan Sistem Informasi Nilai Ujian Online Dengan Gammu. Nugroho(2013) Mengembangkan sistem evaluasi belajar terpadu berbais Web menggunakan Yii Freamwork (Studi kasus :SMA Negeri 3 Salatiga). Tulangow(2011) Mengembangkan Sistem Ujian Berbasis Web. Candra(2012) Mengembangkan Aplikasi Ujian Online di RSBI SMAN 2 Mojokerto.

\section{METODE}

Dalam Pengembangan SIVAJAR (Sistem Informasi Evaluasi Belajar) Berbasis Web (Studi Kasus : SMK Negeri 3 Singaraja) ini menggunakan model Waterfall. Metode ini bisa disebut dengan classic life cycle. Model ini melakukan pendekatan secara sistematis dan terurut mulai dari level kebutuhan sistem kemudian menuju tahap analisis, desain, coding, testing / verification, dan maintenance. Disebut dengan Waterfall karena tahap demi tahap yang dilalui harus menunggu selesainya tahap sebelumnya dan berjalan berurutan.

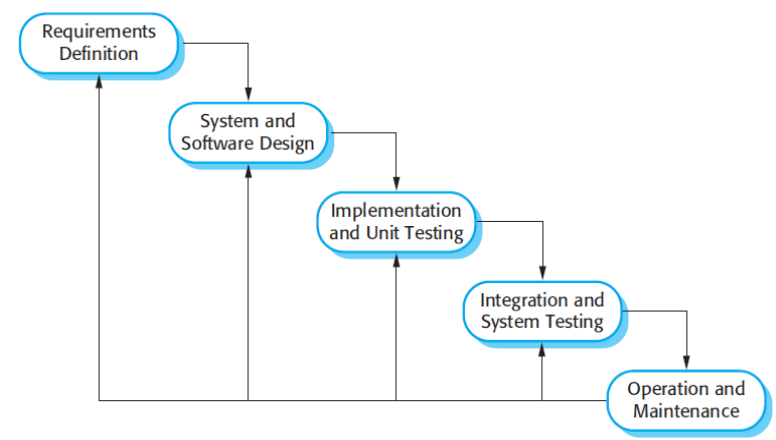

Gambar 1. Pemodelan Waterfall (Sommerville, 2011)

\section{A. Definisi Kebutuhan}

Tahap ini merupakan tahap awal dalam pembuatan suatu sistem sebagai pendukung sistem yang akan dibangun. Adapun implementasi kegiatan pada tahap ini meliputi pengumpulan data dan analisis data. Pengumpulan data merupakan proses pertama yang harus dilakukan, dengan adanya sebuah data, maka akan lebih mudah dalam merancang ataupun membangun sebuah sistem. Berdasarkan hasil analisis terhadap proses akademik yang ada di SMKN 3 Singaraja, terdapat kebutuhan-kebutuhan yang diperlukan dalam mengembangkan sistem evaluasi belajar ini, yaitu : (1) Kebutuhan Fungsional Perangkat Lunak dimana sistem yang dikembangkan dirancang agar dapat mengimplementasikan kebutuhan fungsional berdasarkan user sebagai berikut: siswa : melihat jadwal evaluasi, mengikuti evaluasi, melihat langsung hasil evaluasi. Guru : mengelola soal, mengelola evaluasi. Orang tua siswa: menerima SMS hasil evaluasi siswa. Admin : mengelola semua data kecuali data evaluasi yang dikelola oleh masing-masing guru mata pelajaran. (2) Kebutuhan Non Fungsional Perangkat Lunak yaitu Aplikasi memiliki rancangan antarmuka perangkat lunak yang responsive dan user friendly, Sistem digunakan pada $\mathrm{PC} /$ komputer menggunakan browser, Sistem dilengkapi fitur sms gateway untuk proses pengiriman pesan, Sistem dilengkapi dengan keamanan SQL Injection Protection, Form Validation, dan keamanan lain yang dapat diterapkan. 


\section{B. Desain Sistem dan Software}

Pada tahap ini dilakukan perancangan sistem dan antarmuka sistem.

\section{Use Case Diagram}

Use case diagram akan merepresentasikan interaksi antara aktor dengan sistem dan menggambarkan fungsionalitas yang diharapkan dari sebuah sistem. Aktor adalah sebuah entitas manusia atau mesin yang berinteraksi dengan sistem dan melakukan pekerjaan tertentu. use case diagram pada Pengembangan SIVAJAR (Sistem Informasi Evaluasi Belajar) Berbasis Web (Studi Kasus : SMK Negeri 3 Singaraja) dapat dilihat pada gambar 2 .

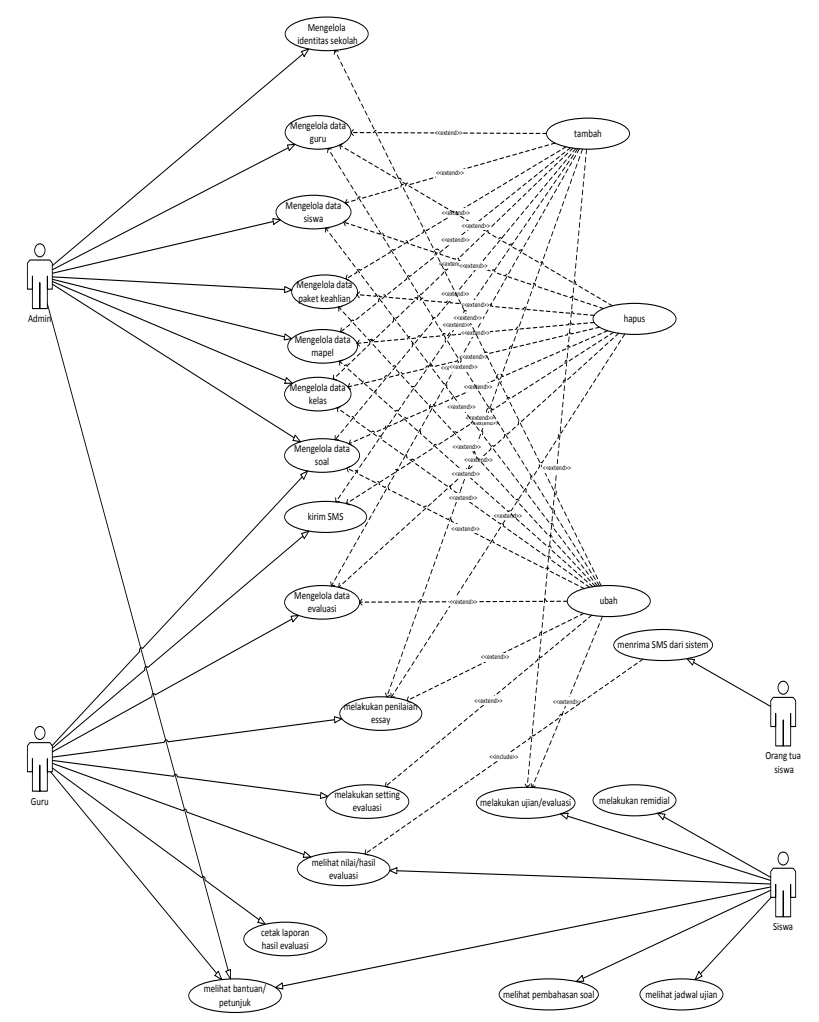

Gambar 2. Use Case Diagram Sistem Evaluasi Belajar SMK (Studi Kasus : SMKN 3 Singaraja)

\section{Activity Diagram}

Activity diagram menggambarkan berbagai alir aktivitas dalam sistem yang sedang dirancang. Activity diagram merupakan state diagram khusus, di mana sebagian besar state adalah action dan sebagian besar transisi di-trigger oleh selesainya state sebelumnya (internal processing). Oleh karena itu activity diagram tidak menggambarkan behaviour internal sebuah sistem (dan interaksi antar subsistem) secara eksak, tetapi lebih menggambarkan proses-proses dan jalurjalur aktivitas dari level atas secara umum (Dharwiyanti, 2003). Berikut merupakan beberapa gambar activity diagram dari sistem yang dikembangkan.

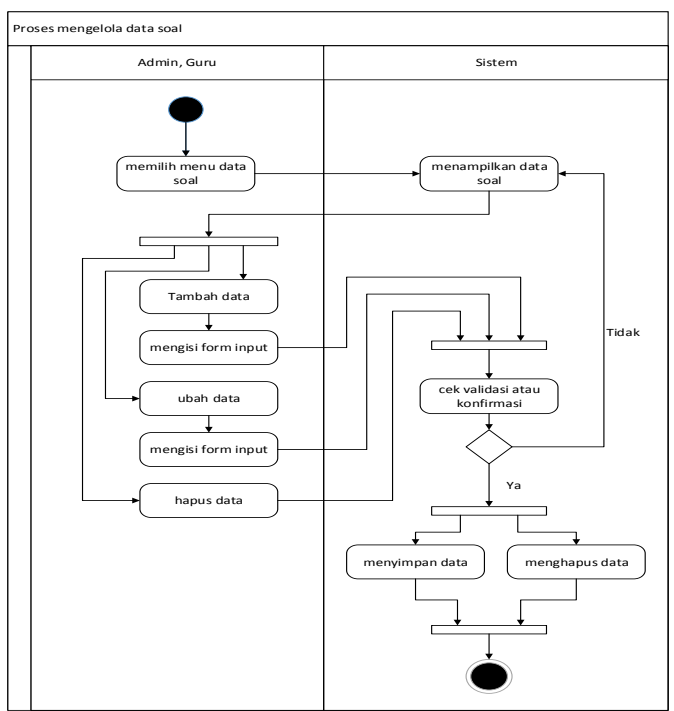

Gambar 3. Activity kelola data soal

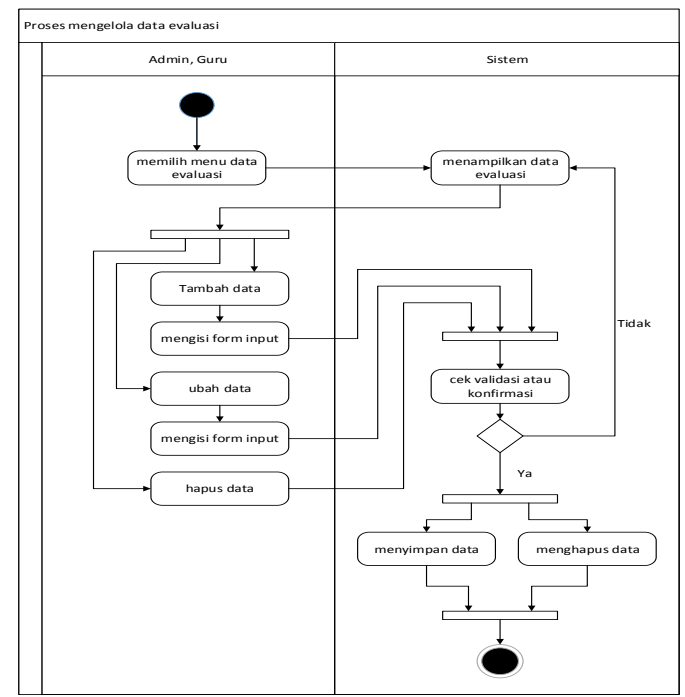

Gambar 4. Activity kelola data evaluasi 


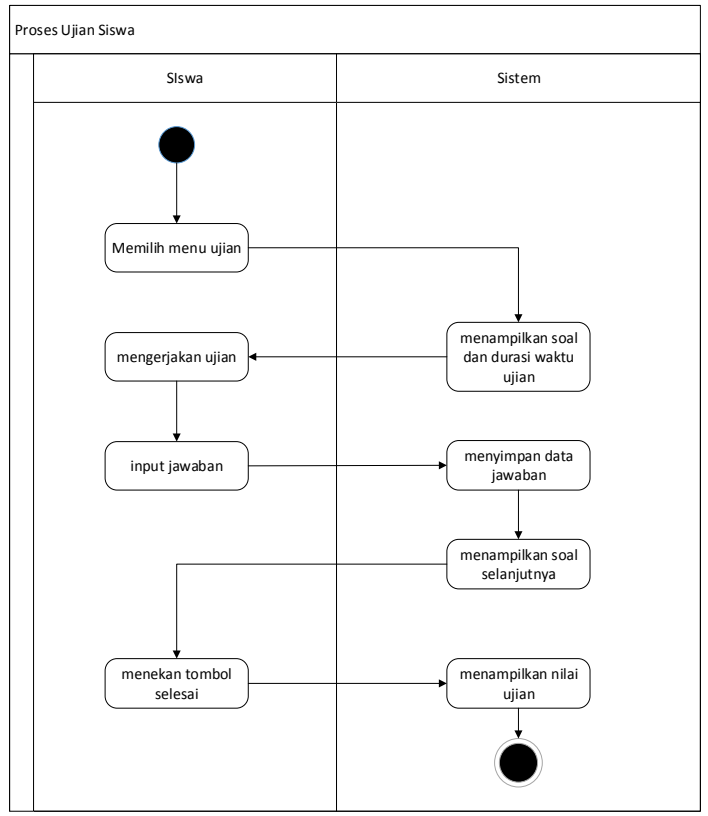

Gambar 5. Activity Proses Evaluasi Siswa

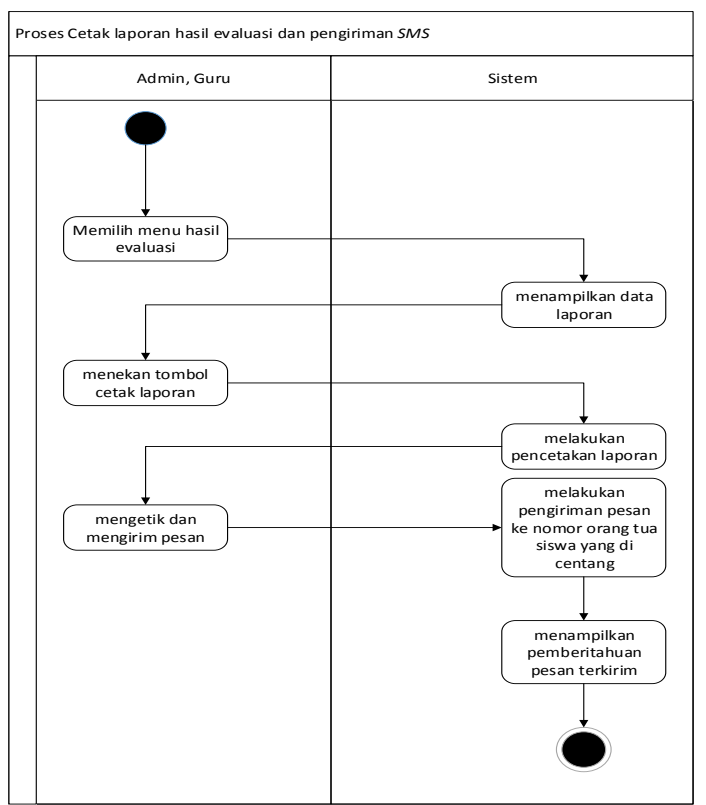

Gambar 6. Activity Cetak Laporan Hasil Evaluasi dan Kirim SMS

\section{Rancangan Tabel Perangkat Lunak}

Dalam sistem yang dikembangkan terdapat 25 rancangan tabel yaitu tabel admin, tabel siswa, tabel guru, bidang keahlian, program keahlian, paket keahlian, kelas, kelas evaluasi, tingkat, time, keluarga siswa, mapel, materi, tahun ajaran, lembar evaluasi, jawaban siswa, hasil evaluasi, guru mapel, soal evaluasi, soal pilihan ganda, soal true/false, soal simple answer, soal essay, soal calculated, identitas sekolah.

D. Implementasi
Tahap ini rancangan yang telah dibuat diimplementasikan ke dalam bentuk kode program. Rancangan yang telah dibuat diterjemahkan ke dalam suatu bahasa pemrograman Web. Sistem evaluasi belajar ini dibangun menggunakan bahasa pemrograman PHP dengan framework Laravel dan Gammu sebagai modul untuk mengirim SMS. Berdasarkan analisis yang dilakukan, perangkat keras(hardware) dan perangkat lunak (software) yang dibutuhkan dalam Pengembangan SIVAJAR : Sistem Informasi Evaluasi Belajar Berbasis Web (Studi Kasus : SMK Negeri 3 Singaraja) adalah sebagai berikut:

1. Kebutuhan Perangkat Lunak (software)

\begin{tabular}{|l|l|l|}
\hline Kebutuhan & $\begin{array}{l}\text { Perangkat } \\
\text { Lunak }\end{array}$ & $\begin{array}{l}\text { Spesifikasi } \\
\text { Minimum }\end{array}$ \\
\hline Server & Web & Apache \\
& Server & 2.4 .18 \\
\cline { 2 - 3 } & Scripting & PHP 7.0.1 \\
\cline { 2 - 3 } & Database & $\begin{array}{l}\text { MySQL } \\
5.7 .9\end{array}$ \\
\cline { 2 - 3 } & Sistem & Windows 7 \\
\hline \multirow{5}{*}{ Client } & Operasi & \\
\cline { 2 - 3 } & Web & Mozilla \\
& Browser & Firefox \\
\hline & Sistem & Windows 7 \\
& Operasi & \\
\cline { 2 - 3 } & Web & Mozilla \\
& Browser & Firefox \\
\hline
\end{tabular}

2. Kebutuhan Perangkat Keras (hardware)

\begin{tabular}{|l|l|l|}
\hline Kebutuhan & $\begin{array}{l}\text { Perangkat } \\
\text { Keras }\end{array}$ & $\begin{array}{l}\text { Spesifikasi } \\
\text { Minimum }\end{array}$ \\
\hline Server & Processor & $\begin{array}{l}\text { Intel Core } \\
\text { i3 }\end{array}$ \\
\cline { 2 - 3 } & RAM & 2 GB \\
\cline { 2 - 3 } & Hardisk & 320 GB \\
\cline { 2 - 3 } & $\begin{array}{l}\text { Keyboard } \\
+ \text { Mouse }\end{array}$ & $\begin{array}{l}\text { Semua } \\
\text { jenis }\end{array}$ \\
\cline { 2 - 3 } & Monitor & $\begin{array}{l}\text { Semua } \\
\text { jenis }\end{array}$ \\
\cline { 2 - 3 } & Modem & $\begin{array}{l}\text { Huawei } \\
\text { Vodafone } \\
\text { K3765 }\end{array}$ \\
\hline Client & Processor & $\begin{array}{l}\text { Intel } \\
\text { Pentium } \\
\text { celeron }\end{array}$ \\
\hline & RAM & 512 MB \\
\cline { 2 - 3 } & Hardisk & 40 GB \\
\cline { 2 - 3 } & Keyboard & Semua \\
\cline { 2 - 3 } & &
\end{tabular}




\begin{tabular}{|l|l|l|}
\hline & + Mouse & jenis \\
\cline { 2 - 3 } & Monitor & $\begin{array}{l}\text { Semua } \\
\text { jenis }\end{array}$ \\
\hline
\end{tabular}

\section{E. Integrasi dan Sistem Testing}

Perlu dilakukannya pengujian untuk menghasilkan aplikasi yang baik, dalam tahap ini akan dilakukan pengujian terhadap aplikasi yang dibuat. Pengujian ini bertujuan untuk mengetahui kekurangan dan kelemahan maupun kesalahan (error) dari aplikasi yang dikembangkan. Sehingga aplikasi masih bisa diperbaiki untuk mengurangi kesalahan-kesalahan yang terjadi sebelum diimplementasikan ke masyarakat luas. Jenis pengujian yang akan digunakan adalah Blackbox testing, Whitebox testing dan Usibility Testing yang meliputi (1) wawancara, (2) task sekenario, (3) kuisioner SUS.

\section{HASIL DAN PEMBAHASAN}

Dari hasil penelitian didapatkan yaitu implementasi struktur data perangkat lunak, implementasi antarmuka perangkat lunak dan hasil pengujian yaitu pengujian black box, white box dan usibility testing.

\section{A. Implementasi Struktur Data Prangkat Lunak \\ Dari hasil pengembangan,} implementasi struktur data prangkat lunak terdapat 25 tabel yaitu tabel admin, tabel siswa, tabel guru, bidang keahlian, program keahlian, paket keahlian, kelas, kelas evaluasi, tingkat, time, keluarga siswa, mapel, materi, tahun ajaran, lembar evaluasi, jawaban siswa, hasil evaluasi, guru mapel, soal evaluasi, soal pilihan ganda, soal true/false, soal simple answer, soal essay, soal calculated, identitas sekolah.

\section{B. Implementasi Antarmuka Perangkat Lunak \\ Pada implementasi rancangan} antarmuka perangkat lunak akan dipaparkan tampilan hasil pengembangan dari sistem ini. Tampilan dalam sistem ini terdiri dari halaman admin, guru dan siswa. Berikut pemaparan lebih detail mengenai implementasi rancangan antarmuka perangkat lunak sistem informasi evaluasi belajar berbasis web (studi kasus : SMKN 3
Singaraja). Berikut adalah beberapa tampilan antarmuka sistem yang dikembangkan.

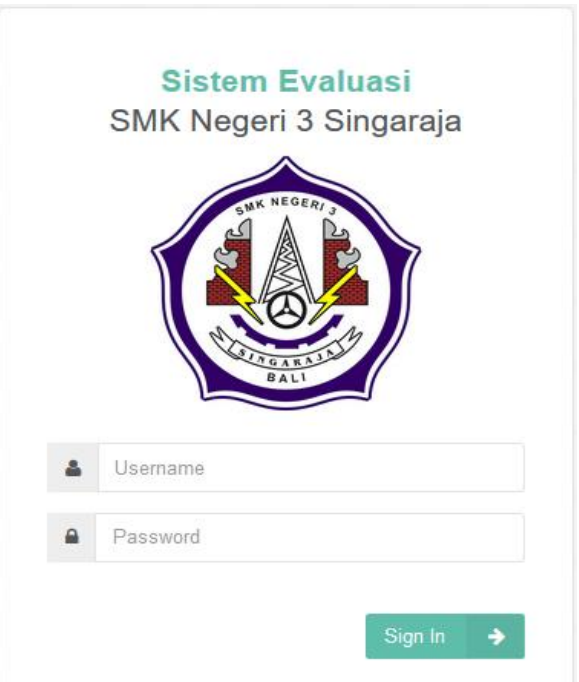

Gambar 7. Implementasi Halaman login
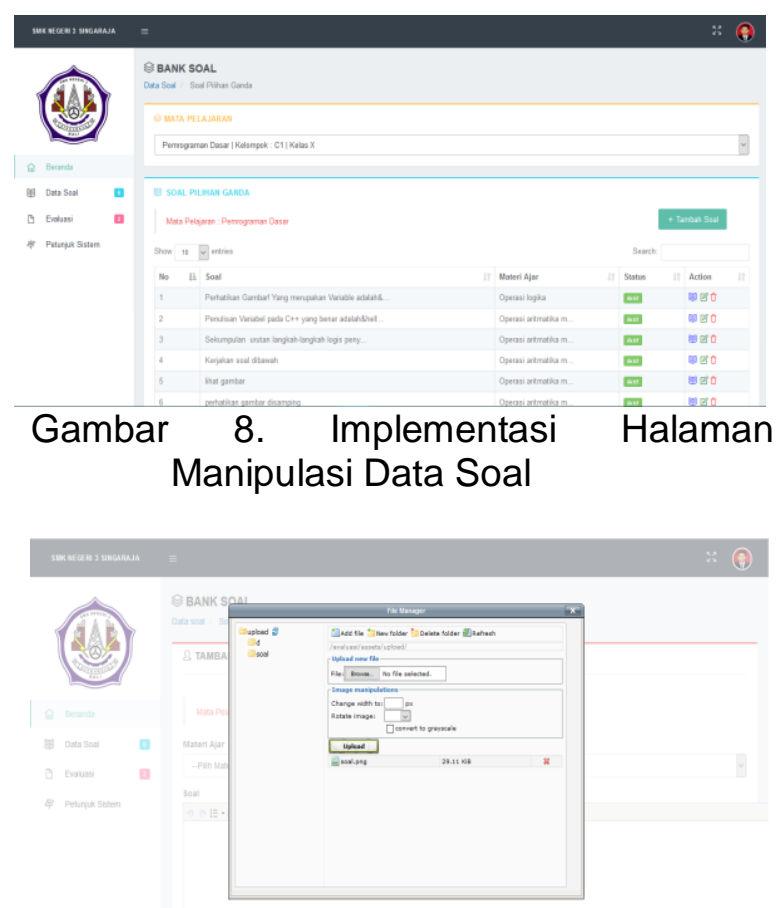

Gambar 9. Implementasi Halaman Manipulasi Gambar Soal 


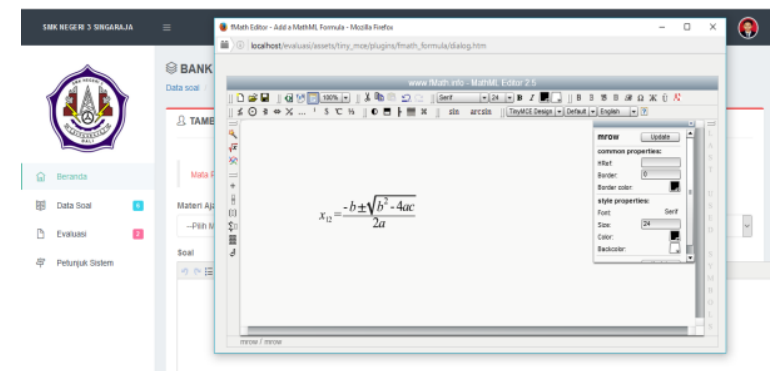

Gambar 10. Implementasi Halaman tambah soal

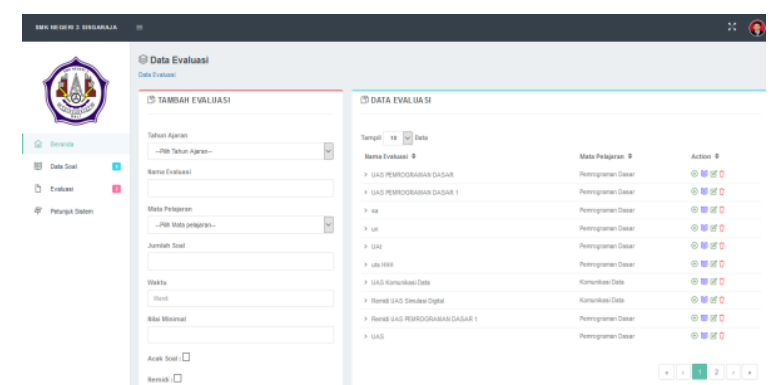

Gambar 11. Implementasi Halaman tambah evaluasi
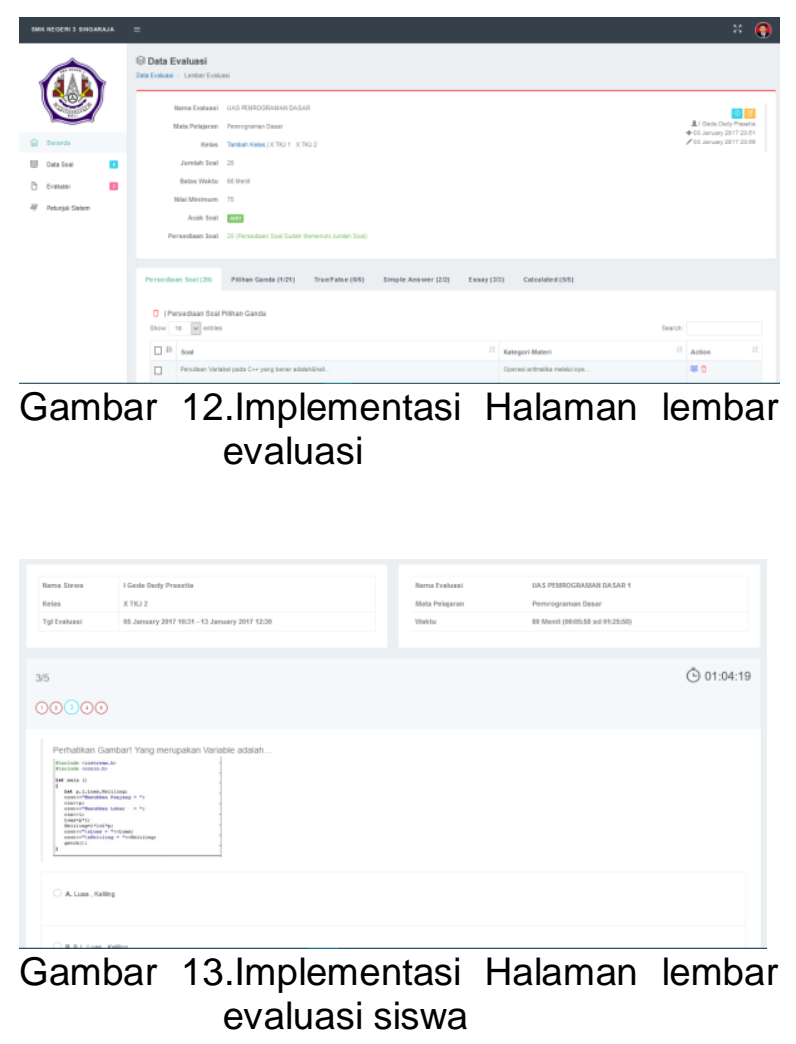
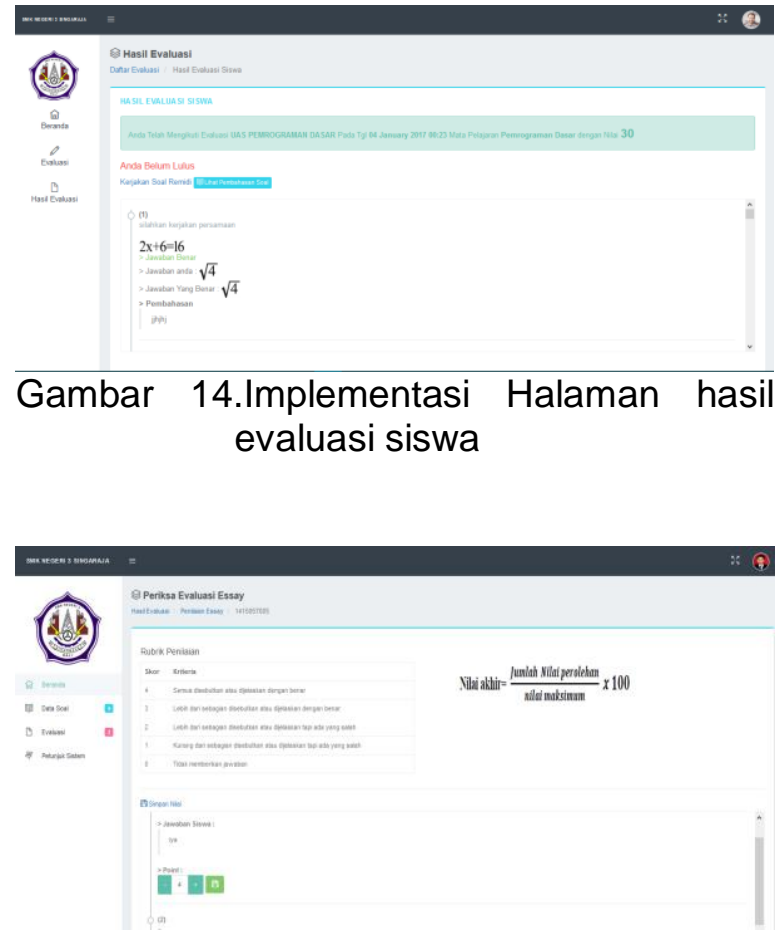

Gambar 15.Implementasi Halaman Rubrik Penilaian Essay

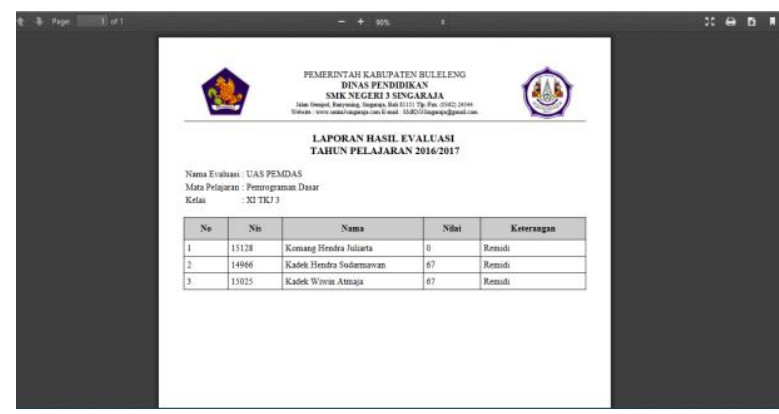

Gambar 16.Implementasi Halaman laporan hasil evaluasi

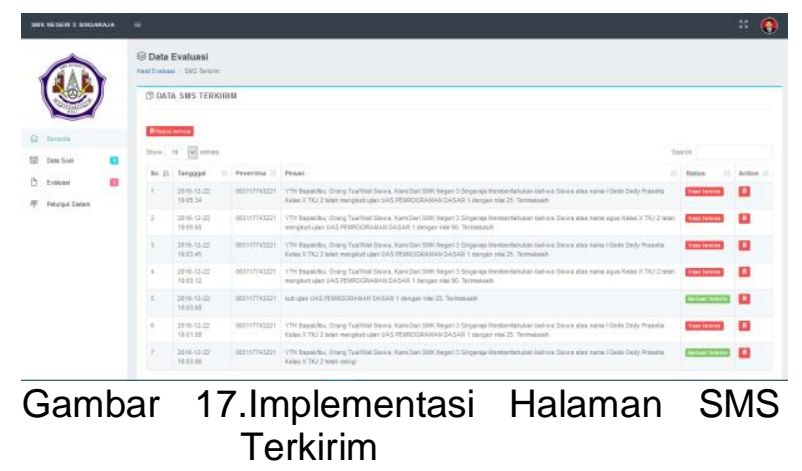




\section{Pengujian Perangkat Lunak}

Pengujian perangkat lunak merupakan proses menjalankan dan mengevaluasi sebuah perangkat lunak untuk menguji apakah perangkat lunak sudah memenuhi persyaratan atau belum untuk menentukan perbedaan antara hasil yang diharapkan dengan hasil sebenarnya. Pengujian yang dilakukan pada penelitian ini adalah black box testing, white box testing dan usability testing.

\section{Pengujian black box}

Blackbox testing dilaksanakan pada tanggal 16 Januari 2017 oleh 1 orang penguji, yaitu I Gede Pande Yogianto Sutanaya. Pengujian dilakukan sesuai dengan item uji yang telah dirancan. Dari hasil pengujian black box untuk uji fungsional sistem dapat dinyatakan bahwa semua fungsi-fungsi pada sistem telah berjalan dengan baik.

\section{Pengujian white box}

Pelaksanaan pengujian white box perangkat lunak berupa pengujian algoritma dilakukan oleh penulis pada tanggal 14 Januari 2017. Dari hasil pengujian white box untuk uji algoritma tersebut dapat dinyatakan bahwa semua algoritma yang digunakan untuk pembuatan Sistem Informasi Evaluasi Belajar SMKN 3 Singaraja sudah benar dan output sudah sesuai dengan tujuan dari masing-masing algoritma tersebut.

\section{Usibility Testing}

Dari pengujian usibility testing dengan teknik Performance Measuremen didapatkan bahwa sistem yang dikembangkan sudah efektif dimana diketahui persentase jumlah error hanya berjumlah satu, dapat disimpulkan bahwa halaman Sistem Informasi Evaluasi Belajar SMKN 3 Singaraja dari segi pengguna guru dikatakan sudah efektif hanya saja terdapat satu pengguna yang tidak berhasil melakukan satu tugas, hal tersebut dikarenakan kurangnya pemahaman pengguna terhadap penggunaan icon pada tombol dan dari segi engguna siswa juga sudah efektif hanya saja terdapat satu pengguna yang tidak berhasil melakukan satu tugas, hal tersebut dikarenakan pengguna tidak memperhatikan untuk melihat pembahasan soal.

Untuk efisiensi juga didaptkan bahwa sistem yang dikembangkan sudah efisien dimana dengan hasil pengujian statistik dengan Mann Whitney U-test pada waktu pengerjaan tugas responden guru dan siswa kelompok mahir dengan kelompok pemula. secara statistik dari 10 tugas yang diberikan dapat dinyatakan tidak ada perbedaan yang signifikan, meskipun waktu pengerjaan pada responden kelompok mahir sedikit lebih cepat dari responden pemula. Dari kesimpulan ini dapat diputuskan bahwa halaman Sistem Informasi Evaluasi Belajar SMKN 3 Singaraja dari segi pengguna baik guru maupun siswa sudah efisien. Dan dari hasil pengujian dengan kuisioner SUS didapatkan untuk mengetahui kepuasan pengguna dimana Perolehan nilai skor untuk kuesioner responden guru sebesar 79.17 dan untuk siswa sebesar 84.58 dimana skor yang diperoleh guru maupun siswa lebih besar dari skor standar SUS yaitu 68 . Sehingga dapat dikatakan bahwa responden guru maupun siswa sudah puas menggunakan Sistem Informasi Evaluasi Belajar SMKN 3 Singaraja.

\section{SIMPULAN DAN SARAN}

Pengembangan SIVAJAR (Sistem Informasi Evaluasi Belajar) Berbasis Web (Studi Kasus : SMK Negeri 3 Singaraja) dirancang dengan menggunakan pemodelan use case dan activity diagram. Sistem diimplementasikan menggunakan bahasa pemrograman PHP dan Javascript dengan framework laravel serta Sublime sebagai code editor. Pengujian dilakukan dengan beberapa cara dan mendapatkan hasil sebagai berikut. Pertama pengujian black box, mendapatkan hasil semua fungsi dan fitur yang ada didalam sistem dapat berjalan dengan baik. Kedua adalah pengujian white box, didapatkan hasil bahwa semua source code dan logika-logika yang ada dalam sistem telah berjalan dengan baik. Hasil pengujian yang ketiga, yaitu usibility testing untuk menguji efektifitas dan efisiensi sistem serta untuk mengetahui kepuasan pengguna dimana didapatkan hasil bahwa sistem sudah efektif, efisien dan pengguna puas menggunakan sistem. 


\begin{abstract}
Berdasarkan hasil penelitian pengembangan dan kesimpulan, dapat disarankan bagi pembaca yang ingin mengembangkan bahwa fitur-fitur dan tipe soal agar bisa ditambahkan lagi supaya soal yang ditampilkan bisa lebih berfariasi dan lebih lengkap. Serta sistem hanya menangani evaluasi pada ranah kognitif, sehingga diharapkan agar bisa dikembangkan lagi sehingga nantinya bisa diterapkan untuk proses evaluasi belajar yang lebih luas.
\end{abstract}

\section{DAFTAR PUSTAKA}

Acho. (2008). SMS Gateway Menggunakan Gammu. Retrieved from http://www.muhadkly.net

Ardana, Y. K. (2013). Pemrograman PHP dengan Codelgniter: Blackbox. Purwokerto: Jasakom.

Candra, A. N. (2012). Aplikasi Ujian Online di RSBI SMAN 2 Mojokerto. Retrieved from http://eprints. upnjatim.ac.id/3351/1/file_1b.pdf

Dharwiyanti, S., \& Wahono, R. S. (2003). Pengantar Unified Modeling Language(UML). Retrievedfrom: http://setia. staff. gunadarma.ac.id /MateriSuplemenUml.pdf

Gunawan, I., \& Palupi, A. R. (2015). Kerangka Landasan Untuk Pembelajaran, Pengajaran dan Penilaian. Retrieved from: http://ejournal.ikippgrimadiun.ac.id/index.ph p/JPE/article/viewFile/27/26

Jihad, A. d. (2008). Evaluasi Pembelajaran. Yogyakarta: Multi Persindo.

Nugroho, I. H. (2013). Sistem Evaluasi Belajar Terpadu Berbasis Web Menggunakan Yii Freamwork (Studi Kasus : SMA Negeri 3 Salatiga). Retrieved from http:// repository.uksw.edu/bitstream/12345 6789/5339/2/T1_672009083_Full\%2 Otext.pdf
Nurhadianto. (2015). Sistem Informasi Ujian Berbasis Web Server SMK Bina Islam Mandiri (Bisma) Kersana Brebes Tegal. Retrieved from http://cogito.unklab.ac.id/index.php/c ogito/article/download/14/11

Pratiwi. (2015). Sistem Informasi Nilai Ujian Online Dengan Gammu. Retrieved from http://digilib.unila. ac.id/8778/16/BAB\%20III.pdf

Sommerville, I. (2011). Software Engineering 9'th Edition. United States of America: Addison-Wesley.

Syah, M. (2004). Psikologi Pendidikan. Bandung: Remaja Rosdakarya.

Tulangow, B. M. (2011). Sistem Ujian Berbasis Web. Retrieved from http://news.palcomtech.com/wpcontent/uploads/2012/01/BOBBYTE01012011.pdf 